\title{
An investigation on the potential of metal recovery from the municipal waste incinerator in Taiwan
}

\author{
Nae-Wen Kuo ${ }^{\text {a,* }}$, Hwong-Wen Ma ${ }^{b}$, Ya-Mei Yang ${ }^{b}$, Teng-Yuan Hsiao ${ }^{c}$, \\ Chin-Ming Huang ${ }^{b}$ \\ ${ }^{a}$ Graduate Institute of Tourism and Health Science, National Taipei College of Nursing, P.O. Box 22-96, Taipei 10699, Taiwan \\ ${ }^{\mathrm{b}}$ Graduate Institute of Environmental Engineering, National Taiwan University, Taipei, Taiwan \\ ${ }^{\mathrm{c}}$ Department of Tourism, Jin Wen Institute of Technology, Taipei, Taiwan
}

Accepted 8 November 2006

Available online 22 August 2007

\begin{abstract}
This study aimed to identify distribution of metals and to estimate the amount of these metals that can be potentially recovered from incineration residues. First, the partitioning behavior of $\mathrm{Cr}, \mathrm{Cu}, \mathrm{Fe}, \mathrm{Cd}, \mathrm{Al}, \mathrm{Zn}$, and $\mathrm{Pb}$ in bottom ash and fly ash was investigated in one large municipal waste incinerator in Taiwan. In addition, the material flow analysis (MFA) method was used to estimate the material flux of metals within incinerator plant, and to calculate the amount of metal recovery. According to the findings of this study, six metals (Fe, $\mathrm{Al}, \mathrm{Cu}, \mathrm{Zn}, \mathrm{Cr}$, and $\mathrm{Pb}$ ) concentrated in bottom ash mostly, while Cd existed primarily in fly ash. The weight percentages of Fe (4.49\%), $\mathrm{Al}(5.24 \%), \mathrm{Cu}(1.29 \%), \mathrm{Zn}(2.21 \%)$, and $\mathrm{Pb}(0.58 \%)$ in incinerator ash are high, and even higher than the compositions of natural minerals. Finally, the amount of $\mathrm{Cr}, \mathrm{Cu}, \mathrm{Fe}, \mathrm{Cd}, \mathrm{Al}, \mathrm{Zn}$ and $\mathrm{Pb}$ that can be potentially recovered from incineration residues will reach $2.69 \times 10^{2}, 1.46 \times 10^{4}, 4.91 \times 10^{4}, 6.92 \times 10^{1}, 5.10 \times 10^{4}, 1.85 \times 10^{4}$ and $4.66 \times 10^{3}$ ton/yr, respectively.
\end{abstract}

(C) 2007 Elsevier Ltd. All rights reserved.

\section{Introduction}

Since metals are non-renewable resources and the consumption rates of various kinds of metals are increasing continually, resources of metals become more and more scarce. After being used in human society, a lot of metals are discarded as waste in incinerators; hence, incineration residues become enriched with metals. In terms of industrial ecology, incinerator residues are not waste, but are useful resources for human society. Consequently, incinerator residues may be regarded as alternate mineral resources and some metals can be recovered from them.

In addition, the growing production of domestic and industrial wastes in industrialized countries causes serious disposal problems. In Taiwan, more than $1.14 \mathrm{~kg}$ of

\footnotetext{
${ }^{*}$ Corresponding author. Tel.: +8862 23634227; fax: +886223929964. Kuo).

E-mail addresses: ibis@ntcn.edu.tw, nivenkuo@ntu.edu.tw (N.-W.
}

domestic wastes are produced per capita each day, for an equivalent of 24,636 ton every day (Taiwan Environmental Protection Agency, 2004). Incineration is the most largely used techniques for urban waste management. This practice allows reduction of waste volume by up to $90 \%$ (Taiwan Environmental Protection Agency, 2002). However, urban waste incineration generates two types of residues: bottom ash and fly ash. In numerous countries, the public is seriously concerned about the problem of dealing with ash (Kawakami et al., 1996; Thipse et al., 2002). Direct landfilling has been identified as an inappropriate solution, especially over the long-term because of the excessive requirement of land for handling them (Calaminus and Stahlberg, 1998; Ecke et al., 2000).

The concentrations and properties of the metals in bottom ash and fly ash affect the final disposal of incineration residues (Ecke et al., 2000). In general, bottom ash represents between $10 \%$ and $35 \%$ of the total mass of garbage burned, while fly ash represents between $0.3 \%$ and $2 \%$ 
(Bawkon, 1991; Sabbas et al., 2003). During combustion, some metals are volatilized and subsequent nucleation and condensation on fly ash particles occurs, such as As, $\mathrm{Cd}$ and $\mathrm{Hg}$. These metals are enriched in the fly ash fraction and depleted in bottom ash (Abanades et al., 2002; Sabbas et al., 2003).

With scarce natural metal resources, Taiwan imports most of the metals for industrial use from other countries, which is obviously unsustainable from a regional perspective. If metals can be recovered from the waste or from incinerator residues, it will not only reduce the demand for imported metals, but also solve the heavy metal leaching problems of waste treatment. In recent years, some research efforts have viewed incineration residues as alternate mineral resources (Ecke et al., 2000; Keisuke et al., 2001; Kuo et al., 2004). Researchers have tried to recover metals from incineration residues; for example, Beauchesne et al. (2005) used electrochemical techniques to recover $\mathrm{Pb}$ from fly ash using lime. In addition, the techniques for recovering zinc and lead from fly ash from municipal waste incineration have been established in Japan (Nagib and Inoue, 2000; Keisuke et al., 2001). Another pioneer research project in Switzerland has been implemented to combine municipal solid waste treatment with mining, using metal production processes to recover metals from waste (Zeltner and Lichtensteiger, 2002). Hence, incineration residues may become important resources for metal production in the future, and the behavior of metals during incineration should be investigated, first in order to assess the potential of metal recovery from incineration residues.

However, little research is concerned about the behavior of metals in municipal waste incineration in Taiwan, while a lot of research is focused on the toxicity characteristic leaching procedure (TCLP) of hazardous metal species in incinerator ash (Kuo et al., 2004). Hence, the purposes of this study are to find the partition behavior of metals in the municipal waste incinerators in Taiwan, and to assess the potential of metal recovery from the incineration residues. In addition, the material flow analysis (MFA) method of industrial ecology (Graedel and Allenby, 2003) is used to describe the fates of targeted metals in municipal waste incineration plants and to estimate the amount of metal recoverable annually.

\section{Materials and methods}

\subsection{Experimental site}

The site for this research is a large municipal solid waste (MSW) incinerator located in Peitou (Taipei, Taiwan). The characteristics of the Peitou municipal waste incinerator are shown in Table 1. The facility has four incinerator lines and a treatment capacity of 1800 ton/day. The electric energy generated is about $528,948,000 \mathrm{MJ} / \mathrm{yr}$. For 345,224 ton of waste incinerated in 2004, about 12,913 ton of fly ash and used lime, and 45,344 ton of bottom ash were produced.

\subsection{Metal concentrations in bottom ash and fly ash}

Based on the previous study (Huang, 2002), seven metals, including $\mathrm{Cr}, \mathrm{Cu}, \mathrm{Fe}, \mathrm{Cd}, \mathrm{Al}, \mathrm{Zn}$ and $\mathrm{Pb}$, were selected for analysis first because the concentrations of these targeted metals are higher than others from the toxicity characteristic leaching procedure (TCLP) in municipal waste incinerator ash. In this experiment, both bottom ash and fly ash were sampled at the same time, and each sampling site was sampled three times to ensure good representation. After sampling, the total metal concentrations in bottom ash and fly ash were determined in this study. Although recent studies in Taiwan were concerned about concentrations of the extracts of the toxicity characteristic leaching procedure (TCLP), TCLP extracts cannot represent the metal compositions of ash comprehensively (Chen et al., 2004).

Two sets of sampling procedures were implemented during different seasons of 2003, one in July, and the other in October. In general, it took eight consecutive hours to obtain bottom ash and fly ash samples for each sampling procedure. Bottom ash samples were taken from the vibrating conveyors of the furnaces under operation after magnetic separation (Fig. 1). About $1-1.5 \mathrm{~kg}$ of bottom ash was shoveled every hour, and then the composite bottom ash was crushed and sieved $(<10 \mathrm{~mm})$ to remove big pieces such as huge magnetic metals and bricks. Moreover, two diagonal parts of the final quartered composite bottom ash were selected, and this procedure was repeated. Finally, about $2 \mathrm{~kg}$ of ash was collected for subsequent laboratory analysis. In addition, fly ash samples were taken from the various air pollution control devices before the solidification process (Fig. 1). About $1 \mathrm{~kg}$ of fly ash was taken every hour and the composite samples were also quartered. Then, two diagonal parts of the final quartered composite bottom ash were selected, and this procedure was repeated. Finally, about $2 \mathrm{~kg}$ of ash was obtained for further laboratory analysis.

After the samples were pretreated and digested according to the standard method of NIEA S321.62C, metal species in the solid sample digests were analyzed with an inductively coupled plasma-atomic emission spectrometry (ICP-AES) (Agilent 7500 series) based on standard method of NIEA M104.01C. The concentration of the elements, including $\mathrm{Cr}, \mathrm{Cu}, \mathrm{Fe}, \mathrm{Cd}, \mathrm{Al}, \mathrm{Zn}$ and $\mathrm{Pb}$ in the bottom ash and fly ash, were determined. In this experiment, each sample was analyzed seven times to ensure good reproducibility.

\subsection{Material flow analysis for Peitou incinerator}

In addition, a detailed material flow analysis, including bottom ash, fly ash, flue gas and sludge, was performed at the Peitou incinerator plant to describe the fates of targeted metals in the municipal waste incinerator plants and to estimate the amount of metal recovery annually. Material flow analysis (MFA) has been used as a useful tool 
Table 1

Basic information about the Peitou incinerator

\begin{tabular}{ll}
\hline Furnace temperature & $850-1050^{\circ} \mathrm{C}$ \\
Air pollution control device & Semi-dry smoke tower, filter bag system, activated carbon system, and selected non-catalytic reaction system \\
Treatment capacity & 1800 ton $/ 24 \mathrm{~h}$ \\
Incinerator lines & 4 \\
Type & Von Roll Stoker type \\
Operation start date & $05 / 26 / 1999$ \\
\hline
\end{tabular}

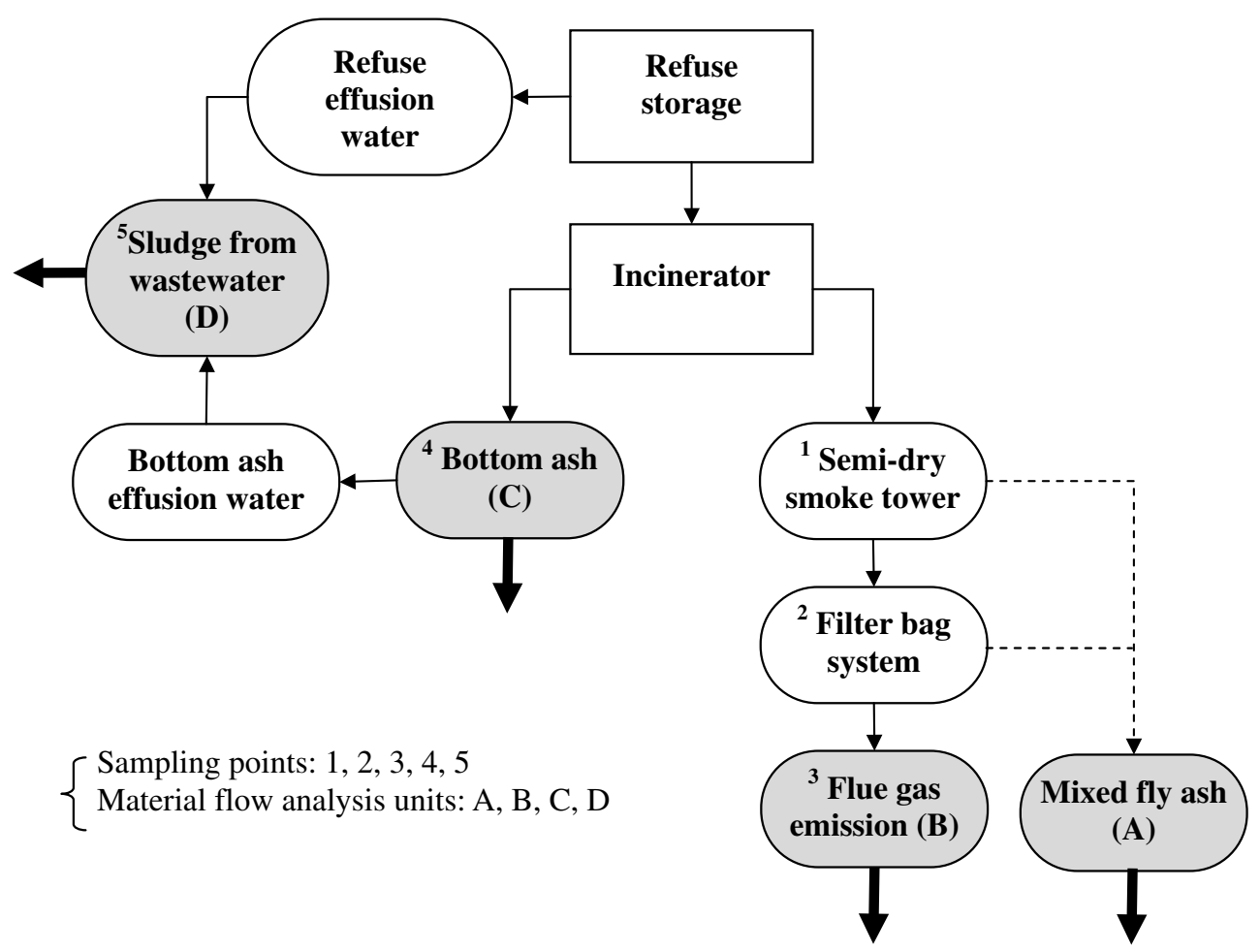

Fig. 1. Framework for material flow analysis of metals in the Peitou incinerator.

for municipal solid waste management since late 1980s (Brunner and Ernst, 1986). Recently, some researchers attempted to apply MFA to municipal waste incinerator management (Morselli et al., 2002, 2005). The calculation of MFA was based on a material balance of goods (substances) for the treatment system in this study. The input for an incineration plant means garbage, and the output for an incineration plant usually means the final products including fly ash, bottom ash, sludge, waste water and flue gas (Brunner and Moench, 1986).

With regard to sludge sampling, about $2 \mathrm{~kg}$ of sludge sample was taken from wastewater treatment plant of the Peitou incinerator. The pre-treatment procedure and analysis method of the sludge samples are the same as those of the ash samples. In addition, three $2 \mathrm{~h}$ flue gas samples were taken in the vertical section of the stack according to the standard method of NIEA A302.71C. Moreover, the samples of flue gas were also analyzed with an inductively coupled plasma-atomic emission spectrometry (ICP-AES) (Agilent 7500 series) according to the standard method of NIEA A302.71C.

\section{Results and discussion}

\subsection{Metal concentrations in bottom ash and fly ash}

The results of the average concentration of seven metals from the Peitou incinerator are shown in Table 2. These compositions were roughly similar to those found in other incinerator ash (Akashi, 1996; IAWG, 1997; Jung et al., 2004). However, in terms of bottom ash, the concentrations of $\mathrm{Cu}$ and $\mathrm{Zn}$ from the Peitou incinerator are higher than those in Japan (Akashi, 1996) and Netherlands (IAWG, 1997) (Table 3). In addition, the concentrations of seven metals in Peitou fly ash are relatively lower than those in Japan (Akashi, 1996) and the Netherlands (IAWG, 1997).

In terms of bottom ash from the Peitou incinerator, the concentrations of $\mathrm{Fe}$ and $\mathrm{Al}$ are extremely high in comparison to those of other metals. The concentrations of $\mathrm{Cd}$ and $\mathrm{Cr}$ in bottom ash are relatively low. With regard to fly ash, the concentrations of $\mathrm{Al}$ and $\mathrm{Zn}$ are extremely high in comparison to those of other metals, while the concentrations of $\mathrm{Cr}$ and $\mathrm{Cd}$ are still relatively low. According to the 
Table 2

Average concentrations of metals in the Peitou incinerator $(\mathrm{mg} / \mathrm{g})$

\begin{tabular}{llcclrr}
\hline Metals & $\mathrm{Cr}$ & $\mathrm{Cu}$ & $\mathrm{Fe}$ & $\mathrm{Cd}$ & $\mathrm{Al}$ & $\mathrm{Zn}$ \\
\hline First season & & & & & & $\mathrm{Pb}$ \\
Fly ash & 0.08 & 0.57 & 2.83 & 0.18 & 8.15 & 8.90 \\
Bottom ash & 0.13 & 19.56 & 39.49 & 0.00 & 44.05 & 14.24 \\
Second season & & & & & 3.01 \\
Fly ash & 0.10 & 0.64 & 5.49 & 0.15 & 18.05 & 10.31 \\
Bottom ash & 0.27 & 5.07 & 41.94 & $3.70 \mathrm{E}-03$ & 34.47 & 10.81 \\
Average of two seasons & & & & & 2.56 \\
Fly ash & $0.09 \pm 0.02$ & $0.61 \pm 0.09$ & $4.16 \pm 2.07$ & $0.16 \pm 0.04$ & $13.10 \pm 6.83$ & $9.62 \pm 1.79$ \\
Bottom ash & $0.20 \pm 0.11$ & $12.32 \pm 8.36$ & $40.71 \pm 13.20$ & $3.16 \mathrm{E}-03 \pm 9.00 \mathrm{E}-04$ & $39.26 \pm 10.54$ & $12.52 \pm 5.78$ \\
\hline
\end{tabular}

Table 3

Concentrations of metals in the Peitou incinerator compared with those in other research $(\mathrm{mg} / \mathrm{g})$

\begin{tabular}{|c|c|c|c|c|c|c|}
\hline Metal & Bottom ash & & & Fly ash & & \\
\hline $\mathrm{Cr}$ & 0.20 & 0.35 & $0.02-3$ & 0.09 & 0.23 & $0.14-1.1$ \\
\hline $\mathrm{Cu}$ & 12.32 & 3.21 & $0.3-8$ & 0.61 & 1.49 & $0.6-3.2$ \\
\hline $\mathrm{Fe}$ & 40.71 & 78.5 & - & 4.16 & 21.6 & - \\
\hline $\mathrm{Al}$ & 39.26 & 102 & - & 13.10 & 64.3 & - \\
\hline $\mathrm{Zn}$ & 12.52 & 5.41 & $1-7$ & 9.62 & 41.8 & 9-70 \\
\hline $\mathrm{Pb}$ & 3.03 & 2.78 & $0.1-14$ & 2.79 & 12.6 & $5.3-26$ \\
\hline
\end{tabular}

compositions of seven metals, they can be divided into three groups based on their weight percentages in ash: $\mathrm{Fe}$ and $\mathrm{Al}$ are one group with the highest weight percentage; $\mathrm{Cu}, \mathrm{Zn}$, and $\mathrm{Pb}$ are the group with the intermediate weight percentage; and $\mathrm{Cd}$ and $\mathrm{Cr}$ are another group with the lowest weight percentage.

In addition, these data seem to be useful to indicate the potential of metal recovery. According to the results of Table 2, Fe and $\mathrm{Al}$ have a lot of potential for recovery from incineration residues. However, these data also show that the recycling of $\mathrm{Fe}$ and $\mathrm{Al}$ before incineration has not been successful in Taiwan. If the materials containing $\mathrm{Fe}$ and $\mathrm{Al}$ can be recycled before combustion, the concentrations of $\mathrm{Fe}$ and $\mathrm{Al}$ in ash will decrease. Since it is best to recycle $\mathrm{Fe}$ and $\mathrm{Al}$ before the combustion process, more effort is needed to increase the recovery of $\mathrm{Fe}$ and $\mathrm{Al}$, such as promoting efficient recycling policy, and improving the capacity of manual and magnetic separation equipment both for raw waste pre-treatment and for bottom ash re-separation.

In addition, the metals of $\mathrm{Cu}, \mathrm{Zn}$, and $\mathrm{Pb}$ also have a potential for recovery from the municipal waste incinerators. The compositions of $\mathrm{Cu}, \mathrm{Zn}$, and $\mathrm{Pb}$ in natural minerals are not high today (e.g., $\mathrm{Cu}: 0.15-0.20 \%, \mathrm{Zn}: 0.17-4.00 \%$, $\mathrm{Pb}: 0.5-4.00 \%$ ) (Zeltner and Lichtensteiger, 2002). According to the findings of this study, the main compositions of $\mathrm{Cu}, \mathrm{Zn}$, and $\mathrm{Pb}$ in both fly ash and bottom ash can reach $1.29 \%, 2.21 \%, 0.58 \%(\mathrm{w} / \mathrm{w})$, respectively. With regard to copper, the content in the incineration residues is higher than that in natural minerals. For lead and zinc, the incineration residues have concentration levels similar to natural minerals. The results are also similar to the case studies in
Japan (Nagib and Inoue, 2000; Keisuke et al., 2001). Some pioneering studies in Japan are being undertaken to recover lead and zinc from fly ash by smelting process.

\subsection{Material flow analysis of metals in the Peitou incinerator}

In order to understand the partitioning characteristics of the targeted metals in the municipal waste incinerator in more detail and to estimate the amount of metal recovery, material flow analysis (MFA) method was used. First, seven output units including the semi-dry smoke tower, filter bag system, flue gas, bottom ash, refuse effusion water, bottom ash effusion water, and sludge from wastewater were monitored. However, according to the results of the Peitou incinerator, the metals in refuse effusion water and bottom ash effusion water are relatively low $(<0.001 \%)$. The metals in wastewater predominantly seem to become concentrated in the sludge after advanced wastewater treatment; consequently, the metal concentrations in the wastewater sector of the Peitou incinerator plant are ignored in this study. The final framework for the material flow analysis of metals in the Peitou incinerator is shown in Fig. 1, and four output units including mixed fly ash (semi-dry smoke tower, and filter bag system), bottom ash, sludge from wastewater, and flue gas were selected and sampled.

The mass distribution of metal species in the incinerator fly ash, bottom ash, sludge from wastewater, and flue gas was calculated by Eq. (1):

$P_{x i}=C_{x i} * W_{i} / S_{x}$ 
Table 4

Compositions of metal species in incinerator ash, sludge, and flue gas

\begin{tabular}{|c|c|c|c|c|c|c|c|c|}
\hline \multirow[t]{2}{*}{ Metal } & \multicolumn{4}{|c|}{ Compositions of metals ( $\mathrm{kg} /$ ton waste, wet weight basis) } & \multicolumn{4}{|c|}{ Metal distribution $(\%)$} \\
\hline & Bottom ash & Fly ash & Sludge & Flue gas & Bottom ash & Fly ash & Sludge & Flue gas \\
\hline $\mathrm{Cr}$ & $2.58 \mathrm{E}-02$ & $4.10 \mathrm{E}-03$ & $4.00 \mathrm{E}-04$ & $2.67 \mathrm{E}-05$ & 85.23 & 13.43 & 1.23 & 0.10 \\
\hline $\mathrm{Cu}$ & 1.59 & $2.73 \mathrm{E}-02$ & $6.00 \mathrm{E}-04$ & $2.54 \mathrm{E}-05$ & 98.28 & 1.68 & 0.04 & 0.00 \\
\hline $\mathrm{Fe}$ & 5.27 & 0.19 & 0.20 & NA & 93.22 & 3.31 & 3.47 & 0.00 \\
\hline $\mathrm{Cd}$ & $4.00 \mathrm{E}-04$ & $7.30 \mathrm{E}-03$ & 0.00 & NA & 5.32 & 94.35 & 0.33 & 0.00 \\
\hline $\mathrm{Al}$ & 5.08 & 0.59 & $4.30 \mathrm{E}-03$ & $4.57 \mathrm{E}-05$ & 89.52 & 10.40 & 0.08 & 0.00 \\
\hline $\mathrm{Zn}$ & 1.62 & 0.43 & $5.50 \mathrm{E}-03$ & NA & 78.75 & 20.99 & 0.27 & 0.00 \\
\hline
\end{tabular}
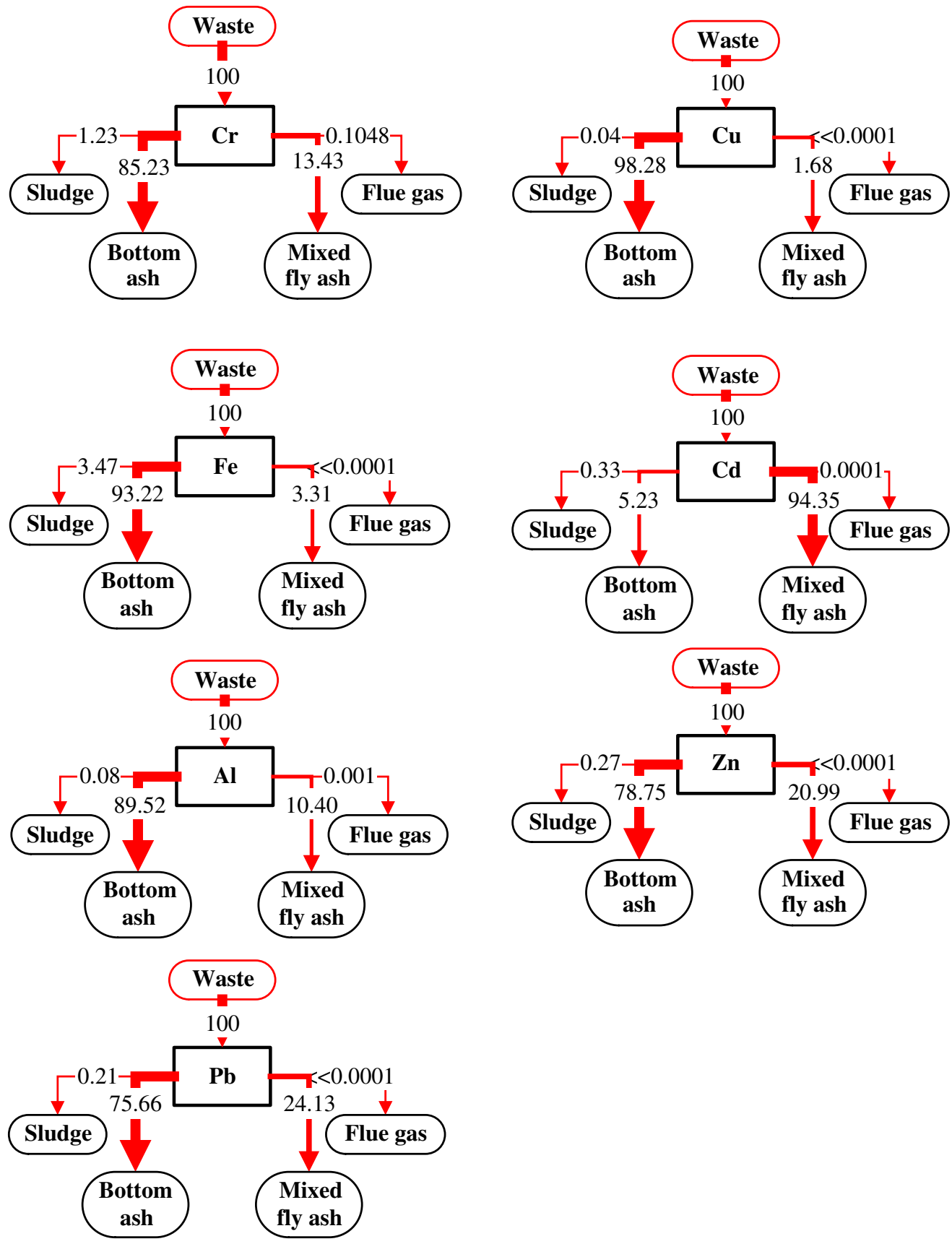

Fig. 2. Material flow of the seven metals in the Peitou incinerator. 
where $P_{x i}$, the percentage of $x$ metal in residue type $i$; $C_{x i}$, the concentration of $x$ metal in residue type $i ; W_{i}$, the production of residue type $i$ per unit time; and $S_{x}$, the total amount of $x$ metal flow to the incinerator per unit time.

The composition results and the partitioning characteristics of the targeted metals are listed in Table 4 . In order to readily calculate the amount of metal recovery, the results are shown as $\mathrm{kg} /$ ton waste, and the weight of waste is in terms of wet weight of waste input into the Peitou incinerator plant. In addition, the final results of the material flow analysis of the seven metals in the Peitou incinerator are shown in Fig. 2.

According to the data in Table 4, the seven target metals are likely to be distributed in bottom ash and fly ash after incineration, while the partitioning of metals into sludge and flue gas is relatively small $(<4 \%)$. Hence, the discussion of metal distribution in this study is focused on the bottom ash and fly ash sectors. In addition, six metals $(\mathrm{Cr}, \mathrm{Cu}, \mathrm{Fe}$, $\mathrm{Al}, \mathrm{Zn}$, and $\mathrm{Pb}$ ) tended to concentrate in the bottom ash, all except $\mathrm{Cd}$. These results indicate that the partitioning of metals during combustion is affected by the fundamental chemical properties of metals such as boiling points, vapor pressures, and specific weights. Cadmium, with a higher vapor pressure and relatively lower boiling point $\left(765^{\circ} \mathrm{C}\right)$, is vaporized by incineration and concentrates more in fly ash while the other metals with lower vapor pressures and higher boiling points are transferred to bottom ash mostly. Since six metals $(\mathrm{Cr}, \mathrm{Cu}, \mathrm{Fe}, \mathrm{Al}, \mathrm{Zn}$, and $\mathrm{Pb}$ ) are likely to concentrate in the bottom ash, the approaches to recover those metals from incinerator residues can be investigated within bottom ash first in Taiwan in the future.

How many metals can be recovered from the residues from municipal waste incineration? Are there economic benefits to the metal recovery industry? The amount of metals that can be recovered may be calculated simply based on the total waste input data and the metal concentrations data in Table 4. According to the statistical data of

Table 5

Amount of metal recovery from incineration residues (ton/yr)

\begin{tabular}{llll}
\hline Metal recovery & Fly ash & Bottom ash & Total \\
\hline Scenario A: Peitou & incinerator plant & & \\
$\mathrm{Cr}$ & 1.42 & 8.91 & $1.03 \times 10^{1}$ \\
$\mathrm{Cu}$ & 9.42 & $5.50 \times 10^{2}$ & $5.60 \times 10^{2}$ \\
$\mathrm{Fe}$ & $6.46 \times 10^{1}$ & $1.82 \times 10^{3}$ & $1.88 \times 10^{3}$ \\
$\mathrm{Cd}$ & 2.52 & 0.14 & 2.66 \\
$\mathrm{Al}$ & $2.04 \times 10^{2}$ & $1.75 \times 10^{3}$ & $1.96 \times 10^{3}$ \\
$\mathrm{Zn}$ & $1.49 \times 10^{2}$ & $5.60 \times 10^{2}$ & $7.09 \times 10^{2}$ \\
$\mathrm{~Pb}$ & $4.32 \times 10^{1}$ & $1.35 \times 10^{2}$ & $1.79 \times 10^{2}$ \\
$\mathrm{Scenario}$ B: Taiwan & & & \\
$\mathrm{Cr}$ & $3.69 \times 10^{1}$ & $2.32 \times 10^{2}$ & $2.69 \times 10^{2}$ \\
$\mathrm{Cu}$ & $2.45 \times 10^{2}$ & $1.43 \times 10^{4}$ & $1.46 \times 10^{4}$ \\
$\mathrm{Fe}$ & $1.68 \times 10^{3}$ & $4.74 \times 10^{4}$ & $4.91 \times 10^{4}$ \\
$\mathrm{Cd}$ & $6.56 \times 10^{1}$ & 3.60 & $6.92 \times 10^{1}$ \\
$\mathrm{Al}$ & $5.31 \times 10^{3}$ & $4.57 \times 10^{4}$ & $5.10 \times 10^{4}$ \\
$\mathrm{Zn}$ & $3.89 \times 10^{3}$ & $1.46 \times 10^{4}$ & $1.85 \times 10^{4}$ \\
$\mathrm{~Pb}$ & $1.13 \times 10^{3}$ & $3.53 \times 10^{3}$ & $4.66 \times 10^{3}$ \\
\hline
\end{tabular}

2004, the waste input to the Peitou incinerator was about 345,224 ton. Consequently, the amounts of the seven targeted metals that can be recovered from bottom ash and fly ash can be estimated; the results are shown in Table 5 . In summary, the total amounts of $\mathrm{Cr}, \mathrm{Cu}, \mathrm{Fe}, \mathrm{Cd}, \mathrm{Al}$, $\mathrm{Zn}$, and $\mathrm{Pb}$ that could be recovered from the Peitou incinerator annually are $1.03 \times 10^{1}, 5.60 \times 10^{2}, 1.88 \times 10^{3}, 2.66$, $1.96 \times 10^{3}, 7.09 \times 10^{2}$, and $1.79 \times 10^{2}$ ton, respectively. The quantities that can be recovered are so huge, and represent only one case of the total 18 municipal waste incinerators under operation in Taiwan. Hence, if the compositions of metal species in all incinerator ashes in Taiwan are the same as those in the Peitou incinerator, and all waste (about 24,636 ton per day) in Taiwan is combusted, then the amount of metal recovery can also be estimated. According to the data in Table 5, the amount of $\mathrm{Cr}$, $\mathrm{Cu}, \mathrm{Fe}, \mathrm{Cd}, \mathrm{Al}, \mathrm{Zn}$, and $\mathrm{Pb}$ that could be recovered from incineration residues would reach $2.69 \times 10^{2}, 1.46 \times 10^{4}$, $4.91 \times 10^{4}, \quad 6.92 \times 10^{1}, \quad 5.10 \times 10^{4}, \quad 1.85 \times 10^{4} \quad$ and $4.66 \times 10^{3}$ ton/yr, respectively.

Since metals recovery from incineration residues seems to have a lot of potential to develop according to the findings of this study, the next step of our research will try to survey and establish the available technologies and methods to recover metals from bottom ash and fly ash. The technologies to recover $\mathrm{Fe}, \mathrm{Al}, \mathrm{Zn}, \mathrm{Cu}$ and $\mathrm{Zn}$ probably should be investigated with priority. In addition, the treatment cost, and importantly, the total environmental cost of metal recovery also need to be assessed in the future.

\section{Conclusion}

In terms of industrial ecology, incinerator residues are not waste; they may be regarded as alternate mineral resources and some metals can be recovered from them. One municipal waste incinerator in Taiwan was selected to investigate the partitioning characteristics of seven targeted metals $(\mathrm{Cr}, \mathrm{Cu}, \mathrm{Fe}, \mathrm{Cd}, \mathrm{Al}, \mathrm{Zn}$, and $\mathrm{Pb})$, and to assess the potential of recovering these metals. In addition, the material flow analysis method was used to describe the detailed metal behavior in the incinerator and to calculate the amounts of metal that could be recovered. According to the findings of this study, the weight percentages of some metals in the incinerator ash are high, and even higher than the compositions of natural minerals such as $\mathrm{Fe}(4.49 \%)$, $\mathrm{Al}$ (5.24\%), $\mathrm{Cu}(1.29 \%), \mathrm{Zn}(2.21 \%)$, and $\mathrm{Pb}(0.58 \%)$.

The MFA method is a useful tool for establishing the material flow model of the metals in incinerators. A major advantage of the MFA method is that it accounts for stocks of the selected metals in the incinerator and can be used to predict future flows to the environment under different management scenarios. The information derived from MFA can be used to develop more comprehensive waste management policies. According to the results of the MFA, the metals are likely to be distributed into bottom ash and fly ash after incineration, while the partitioning of metals into sludge and flue gas is relatively small 
$(<4 \%)$. In addition, six metals $(\mathrm{Fe}, \mathrm{Al}, \mathrm{Cu}, \mathrm{Zn}, \mathrm{Cr}$, and $\mathrm{Pb})$ concentrated in bottom ash mostly, while $\mathrm{Cd}$ existed mainly in fly ash. Those findings may be useful for integrating municipal solid waste management and the metal recovery industry in Taiwan and other similar countries.

\section{Acknowledgements}

The authors would like to thank the financial support of the Environmental Protection Administration in Taiwan, and the suggestions from Brunner, P.H., Moore, S., and Yang, W.F.

\section{References}

Abanades, S., Flamant, G., Gagnepain, B., Gauthier, D., 2002. Fate of heavy metals during municipal solid waste incineration. Waste Management Research 20, 55-68.

Akashi, T., 1996. Development of fly ash treatment technology by electricresistance melting. In: Seventh Research Presentation Seminar Proceedings I, The Japan Society of Waste Management Experts, pp. 430432 .

Bawkon, B., 1991. Incineration technologies for managing solid waste. Pollution Engineering 23, 96-109.

Beauchesne, I., Meunier, N., Drogui, P., Hausler, R., Mercier, G., Blais, J.F., 2005. Electrolytic recovery of lead in used lime leachate from municipal waste incinerator. Journal of Hazardous Materials B120, 201-211.

Brunner, P.H., Ernst, W.R., 1986. Alternative methods for the analysis of municipal solid waste. Waste Management and Research 4, 147160.

Brunner, P.H., Moench, H., 1986. The flux of metals through municipal solid waste incinerators. Waste Management and Research 4, 105119.

Calaminus, B., Stahlberg, R., 1998. Continuous in-line gasification/ vitrification process for thermal waste treatment: process technology and current status of projects. Waste Management 18, 547-556.

Chen, S.J., Hung, M.C., Huang, K.L., Hwang, W.I., 2004. Emission of heavy metals from animal carcass incinerators in Taiwan. Chemosphere 55, 1197-1205.

Ecke, H., Sakanakura, H., Matsuto, T., Tanaka, N., Lagerkvist, A., 2000. State-of-the-art treatment processes for municipal solid waste inciner- ation (MSWI) residues in Japan. Waste Management and Research 18, $41-51$.

Environmental Protection Agency, 2002. Environmental Programs: Implementation of the Construction Project of Waste to Energy Plants in Taiwan. EPA, Taipei, ROC.

Environmental Protection Agency, 2004. The 2003 Year Book of Taiwan Environmental Information. EPA, Taipei, ROC, pp. 22-23.

Graedel, T.E., Allenby, B.R., 2003. Industrial Ecology. second ed. Pearson Education, NJ, USA.

Huang, Y.J., 2002. Vitrification of Municipal Solid Waste Incineration Ash. Master Thesis, National Cheng Kung University.

IAWG, 1997. Municipal solid waste incinerator residues. In: Studies in Environmental Sciences, vol. 67. Elsevier, Amsterdam, The Netherlands.

Jung, C.H., Matsuto, T., Tanaka, N., Okada, T., 2004. Metal distribution in incineration residues of municipal solid waste (MSW) in Japan. Waste Management 24, 381-391.

Kawakami, I., Esaki, M., Tetsuyama, I., Sumitomo, M., 1996. Immobilization of fly ash from MSW incinerators and ash-melting furnaces. Waste Management 16, 483-489.

Keisuke, N., Mitsuhiro, T., Hiroshi, Y., Takuya, S., Tetsuo, A., Minoru, T., 2001. Heavy metals recovery system for dust from NKK electricresistance furnace. NKK Technical Review 84, 8-15.

Kuo, Y.M., Lin, T.C., Tsai, P.J., 2004. Metal behavior during vitrification of incinerator ash in a coke bed furnace. Journal of Hazardous Materials B109, 79-84.

Morselli, L., Passarini, F., Bartoli, M., 2002. The environmental fate of heavy metals arising from a MSW Incineration Plant. Waste Management 22, 875-881.

Morselli, L., Bartoli, M., Bertacchini, M., Brighetti, A., Luzi, J., Passarini, F., Masoni, P., 2005. Tools for evaluation of impact associated with MSW incineration: LCA and integrated environmental monitoring system. Waste Management 25, 191-196.

Nagib, S., Inoue, K., 2000. Recovery of lead and zinc from fly ash generated from municipal incineration plants by means of acid and/or alkaline leaching. Hydrometallurgy 56, 269-292.

Sabbas, T., Polettini, A., Pomi, R., Astrup, T., Hjelmar, O., Mostbauer, P., Cappai, G., Magel, G., Salhofer, S., Speiser, C., Heuss-Assbichler, S., Klein, R., Lechner, P., 2003. Management of municipal solid waste incineration residues. Waste Management 23, 61-88.

Thipse, S.S., Schoenitz, M., Dreizin, E.L., 2002. Morphology and composition of the fly ash particles produced in incineration of municipal solid waste. Fuel Processing Technology 75, 173-184.

Zeltner, C., Lichtensteiger, T., 2002. Thermal waste treatment and resource management - a petrologic approach to control the genesis of materials in smelting processes. Environmental Engineering Policy $3,75-86$ 